\title{
AN ATTEMPT AT AN EVALUATION OF EDITORIAL WORK IN TRANSLATED SOURCES OF ROMAN LAW IN CONTEMPORARY POLAND
}

It is obvious how vital law sources are for Roman law scholars ${ }^{1}$. However, the problem does not lie in the lack of access to sources, as obtaining academically recognised publications on Roman law is relatively easy, much as in the case of non-juristic sources related to the history of politics, literature, or philosophy. It seems that the major obstacle for a contemporary Roman law researcher, especially a younger one, may be the language barrier, resulting from insufficient skills in classical languages, especially Latin and Greek. This is where, what we may call, "gifts of fortune" come to one's aid, in the form of Roman law

\footnotetext{
* Ph.D. habil., Prof. Extraordinary, Faculty of Law and Administration, Nicolaus Copernicus University in Torun, Poland; e-mail: mossacc@uni.torun.pl. He finished his legal studies in The Law and Administration Faculty in Copernicus University in Torun in 1974. In the beginning W.M. was an attorney at law (until 1993). The academic life of W.M. started in 1991 (tutor, professor: 2003). His main books: Accusator w rzymskich procesach de repetundis w okresie republiki [The Accuser in the Roman Trials of Extortions], Torun 1994; Azyl w późnym Cesarstwie Rzymskim (confugium ad statuas, confugium ad ecclesias) [The Asylum in the Late Roman Empire (confugium ad statuas, confugium ad ecclesias)] Torun 2000; Wybrane problemy rzymskiego prawa publicznego [Selected Problems of Roman Public Law], Torun 2013. He is the author of about 40 articles. Main participation in international academic conferences (SIDA): in Amsterdam, Brussels, Vienna, and also in Madrid.

1 Separate publications containing comprehensive discussions of Roman source text studies are rather rare in Poland. Cf.: T. Dydyński, Historia źródet prawa rzymskiego [The Legal Sources History of Roman Law], Warszawa: Skład główny w księgarni E. Wende i S-ka 1904, passim.
} 
sources published in Polish. However, in my analysis, I focus only on Roman sources (classics) of normative acts translated into Polish from the ancient originals. Therefore, I also do not quote any collections of text fragments published only in the original language ${ }^{2}$, and which are varied in terms of their form and function; since, as such, they do not provide a relevant research basis for the contemporary reader. I omit such works as, for instance, Noctes Atticae by Aulus Gellius3, which, despite their fundamental importance to jurisprudence, are ultimately of non-juristic nature4. So, the intention of this paper is to exclude any works other than legal classics.

Disregarding for the purpose of this paper the fact that, ideally, the analysis of the presented publications should be preceded by one of the momentous works from the past, like the partial translation of Gai Institutiones done as early as the 19th century by Teodor Dydyński5, I shall focus solely on contemporary editing.

A good way to start is by looking at the list of published translations of Roman law sources 6 :

- M.H. Serejski, Położenie uciskanych warstw ludności u schytku cesarstwa [Status of Oppressed People's Stratums at Falls of Empire] ${ }^{7}$,

2 R. Taubenschlag, Wybór źródet do rzymskiego prawa prywatnego dla użytku seminaryjnego [The Selection of the Sources to Roman Private Law for Seminar Usage], Kraków: Księgarnia Powszechna 1931; alternative edition: R. Taubenschlag, W. Kozubski, Warszawa: Gebethner i Wolf 1947, p. 98. Cf.: J. Wisłocki, Prawo rzymskie w Polsce [The Roman Law in Poland], Warszawa: unknown 1945, p. VIII + 156.

3 Cf.: A. Tarwacka, Aulus Gellius. Attic Nights - more on a whole series of translations and interesting comments by this author: M. Zabłocka, Romanistyka polska w pierwszym dziesięcioleciu XXI wieku [Polish Romanists Science of the First Decade of XXI Century], Warszawa: Liber 2013, p. 26.

4 Also omitting other works which treat the sources selectively: A. Kacprzak, J. Krzynówek, W. Wołodkiewicz, [in:] W. Wołodkiewicz, Regulae iuris. Łacińskie inskrypcje na kolumnach Sąu Najwyższego Rzeczypospolitej Polskiej [Latin Inscriptions on Columns of Polish Republic's Supreme Court], Warszawa: C.H. Beck 2001, p. 159; W. Bojarski, W. Dajczak, A. Sokala, Verba iuris. Reguty i kazusy prawa rzymskiego [Regulae iuris. Rules and Cases of Roman Law], 3rd ed., Torun: TNOiK 2007, p. 197.

5 T. Dydyński, Instytucje Gaja [Institutions of Gaius], Warszawa: Księgarnia H. Natansona 1865.

6 Zabłocka, supra note 4, pp. 25-28.

$7 \quad$ M.H. Serejski, p. 9 - quotes another translation, although without editing details: Teksty źródtowe do nauki historii w szkole średniej [The Sources' Texts for History Secondary School's Education], Book 12, issues 21 and 23 [re: C. Th. XV, 11, 1 and XII, 1, 16]. 
[in:] idem, Upadek Cesarstwa Rzymskiego i początki feudalizmu na Zachodzie $i w$ Bizancjum [The Fall of the Roman Empire and the Beginning of Feudalism in the West and in Byzantium], Warszawa: Polskie Wydawnictwo Naukowe 1954, pp. 9-10,

- S. Łoś, Zachowane fragmenty Prawa XII Tablic [Preserving Fragments of XII Tables], [in:] idem, Sylwetki rzymskie [Roman Silhouette], Warszawa: Państwowy Instytut Wydawniczy PAX 1958, pp. 237-259,

- Gaius, Instytucje [Institutes], J. Rezler (ed.), C. Kunderewicz (transl.), Warszawa: Państwowe Wydawnictwo Naukowe 1982, pp. 479,

- Instytucje Justyniana [Justinian's Institutes], C. Kunderewicz (transl. \& ed.), Warszawa: Państwowe Wydawnictwo Naukowe 1986, pp. 292,

- W. Rozwadowski, Wybór źródet [Selected Sources], [in:] idem, Prawo rzymskie. Zarys wykładu wraz z wyborem źródet [Roman Law. Outline of the Lecture with Selected Sources], 2nd ed., Poznan: Ars boni et aequi 1992, pp. 227-313,

- M. \& J. Zabłoccy, Ustawa XII tablic. Tekst - tłumaczenie - objaśnienia [Lex of XII Tables. Text - Translation - Explanation], Warszawa: Liber 2000, pp. 81,

- Instytucje Gajusa [Gai Institutiones], W. Rozwadowski (trans. \& ed.), $1^{\text {st }}$ ed., Poznań: Ars boni et aequi 2003, pp. 207,

- A. Tarwacka, Leges regiae. Tekst - ttumaczenie - komentarz [Leges regiae. Text - Translation - Commentary], Zeszyty Prawnicze [Journal of Law] 2004, no. 4.1, pp. 233-260,

- E. Loska, Ustawa julijska o przemocy prywatnej. 7 tytut 48 księgi Digestów. Tekst - tłumaczenie - komentarz [Lex Julia of Private Violence. Title 7 of Book 48 of Digest. Text - Translation - Commentary], Zeszyty Prawnicze [Journal of Law] 2006, no. 6.1, pp. 301-307,

- B. Sitek, Tabula Heracleensis (lex Iulia municipalis). Tekst - ttumaczenie - komentarz [Tabula Heracleensis (lex Iulia municipalis). Text Translation - Commentary], Olsztyn: Wydawnictwo Uniwersytetu Warmińsko-Mazurskiego w Olsztynie 2006, pp. 87,

- Tabula Hebana. Rogatio Valeria Aurelia de honoribus meritis Germanici Caesaris. Tablica z Heby. Wniosek konsulów Waleriusza i Aureliusza 
w sprawie uhonorowania zastug Germanika Cezara [Tabula Hebana. Rogatio Valeria Aurelia de honoribus meritis Germanici Caesaris. Table of Heba. The Rogation of Consuls Valerius and Aurelius in the Matter of Honouring the Services of Germanicus Caesar], T. Fabiszak (transl.), P. Sawiński (transl.), M. Stuligrosz (consultory), P. Sawiński (commentary), J. Wiewiorowski (commentary), Poznań: Wydawnictwo Naukowe UAM 2006, pp. 32,

- De religiosis et sumptibus funerum et ut funus ducere liceat - O rzeczach poświęconych [zmartym] i kosztach pochówku oraz jak należy zorganizować pogrzeb. De mortuo inferendo et sepulchro aedificando O grzebaniu zmartych $i$ budowie grobowca; De sepulchro violato O zbezczeszczonym grobie [De religiosis et sumptibus funerum et ut funus ducere liceat - About Things Devoted [to the deceased] and the Expense of a Funeral, and How to carry out Burial. De mortuo inferendo et sepulchro aedificando - About the Funeral, and the building of the Tomb; De sepulchro violato], J. Pudliszewski (transl. \& ed.), Poznań: Wydawnictwo Naukowe UAM 2009, pp. 67,

- T. Palmirski, O różnych regułach dawnego prawa - 17 tytuł 50 księgi Digestów. Tekst - tłumaczenie - komentarz [About Various Rules of Early Law - Title 17 of Book 50 of Digest. Text - Translation Commentary], Studia Prawnicze [Legal Studies] 2007, no. 7.2, pp. 297-345,

- B. Szolc-Nartowski, Digesta Justyniańskie. Księga pierwsza [Justinian's Digest. Book First], Warszawa: Dom Wydawniczy Elipsa 2007, p. 130, nlb. 2,

- A. Dębiński, Komentarz do ustawy julijskiej o bezprawnych zabiegach wyborczych 14 tytut 48 księgi Digestów. Tekst - tłumaczenie - komentarz [The Commentary to Lex Julia on Electoral Corruption - Title 14 of Book 48 of Digest. Text - Translation - Commentary], Studia Prawnicze [Legal Studies] 2008, no. 8.2, pp. 335-346,

- A. Dębiński, Komentarz do ustawy julijskiej o sprzeniewierzeniu, świętokradcach $i$ zatrzymujących [pieniądze publiczne] - 13 tytut 48 księgi Digestów. Tekst - tłumaczenie - komentarz [The Commentary to Lex Julia on Embezzlement (of Public Money), on Sacrilege, and on Moneys Remaining - Title 13 of Book 48 of Digest. Text - 
Translation - Commentary], Studia Prawnicze [Legal Studies] 2008, no. 8.1, pp. 355-367,

- B. Sitek, Lex coloniae Genetivae Iuliae seu Ursonensis i lex Irnitana. Ustawy municypalne antycznego Rzymu. Tekst, ttumaczenie i komentarz [Lex coloniae Genetivae Iuliae seu Ursonensis i lex Irnitana. Municipal Acts of Ancient Rome. Text, Translation and Commentary], Poznań: Ars boni et aequi 2008, pp. 232,

- A. Tarwacka, O pozycji prawnej ludzi - 5 tytut I ksiegi [About the Legal Status of the Human Being - Title 5 of Book 1], Zeszyty Prawnicze [Journal of Law] 2008, no. 8.2, pp. 319-334,

- A. Tarwacka, O osobach sui iuris i alieni iuris - 6 tytut I ksiegi Digestów. Tekst - ttumaczenie - komentarz [About sui iuris and alieni iuris Persons - Title of Book I of Digests. Text - Translation Commentary], Zeszyty Prawnicze [Journal of Law] 2009, no. 9.1, pp. 319-332,

- A. Tarwacka, O podziale rzeczy $i$ ich przymiotach - 8 tytut I ksiegi Digestów. Tekst - ttumaczenie - komentarz [About The Division of things and their Quality - Title 8 of Book I of Digest. Text - Translation Commentary], Zeszyty Prawnicze [Journal of Law] 2009, no. 9.2, pp. 363-375,

- A. Tarwacka, O przysposobieniach $i$ emancypacjach oraz o innych sposobach ustania władzy ojcowskiej - 7 tytuł I księgi Digestów. Tekst ttumaczenie - komentarz [About Adoption and Emancipation, and Other Ways of patria potestas Disability - Title 7 of Book I of Digest. Text - Translation - Commentary], Zeszyty Prawnicze [Journal of Law] 2010, no. 10.1, pp. 275-306,

- A. Tarwacka, O senatorach - 9 tytut I księgi Digestów. Tekst thumaczenie - komentarz [About Senators - Title 9 of Book I of Digest. Text - Translation - Commentary], Zeszyty Prawnicze [Journal of Law] 2010, no. 10.2, pp. 305-316,

- A. Tarwacka, O urzędzie prefekta pretorianów - 11 tytut I ksiegi Digestów. Tekst - ttumaczenie - komentarz [About the Office of Praefectus Praetorio - Title 11 of Book I of Digest. Text - Translation Commentary], Zeszyty Prawnicze [Journal of Law] 2011, no. 11.2, pp. 325-340, 
- A. Tarwacka, O urzędzie kwestora - 13 tytuł I księgi Digestów. Tekst ttumaczenie - komentarz [About the Quaestor's Office - Title 13 of Book I. Text - Translation - Commentary], Zeszyty Prawnicze [Journal of Law] 2011, no. 11.3, pp. 327-332,

- A. Tarwacka, O urzędzie pretorów - 14 tytut I księgi Digestów. Tekst ttumaczenie - komentarz [About the Praetor's Office - Title 14 of Book 1 of Digest. Text - Translation - Commentary], Zeszyty Prawnicze [Journal of Law] 2011, no. 11.4, pp. 419-424,

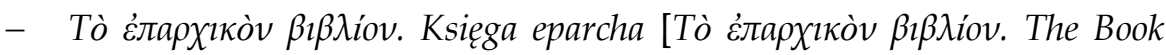
of the Eparch], A. Kotłowska (transl. \& ed.), K. Ilski (introduction), Poznań: Wydawnictwo Naukowe UAM 2011, pp. 85,

- Zbiór prawa Mojżeszowego i rzymskiego. Tekst tacińsko-polski [Compilation of Mosaic and Roman Law. Text Latin-Polish], A. Dębiński (trans. \& ed.), Lublin: Wydawnictwo KUL 2011, pp. 234,

- D. Stolarek, Ustawa julijska o karaniu za cudzołóstwa - 5 tytuł 48 księgi Digestów. Tekst - ttumaczenie - komentarz [Lex Julia about the Penalty for Adultery - Title 5 of Book 48 of Digest. Text - Translation Commentary], Zeszyty Prawnicze [Journal of Law] 2012, no. 12.1, pp. 205-424,

- A. Tarwacka, O urzędzie prefekta straży miejskiej - 15 tytut I ksiegi Digestów. Tekst - ttumaczenie - komentarz [About the Office of the Commander of the City Guard - Title 15 of Book 1 of Digest. Text - Translation - Commentary], Zeszyty Prawnicze [Journal of Law] 2012, no. 12.2, pp. 199-206,

- Digesta Iustiniani. Digesta justyniańskie [Digesta Iustiniani. The Digest of Justinian], T. Palmirski (trans. \& ed.), K. Hilman (transl.), M. Hładyszewska (transl.), H. Wolanin (transl.), J. Zabłocki (transl.), J. Reszczyński (transl.), vol. 1, Kraków: Poligrafia Salezjańska 2013, pp. 571,

- Digesta Iustiniani. Digesta justyniańskie [Digesta Iustiniani. The Digest of Justinian], T. Palmirski (trans. \& ed.), K. Hilman (transl.), M. Hładyszewska (transl.), J. Reszczyński (transl.), H. Wolanin 
(transl.), P. Święcicka (transl.), vol. 2, Kraków: Poligrafia Salezjańska 2013, pp. 5038.

One of the items on the above list which is worth paying special attention to is the translation series printed regularly in "Zeszyty Prawnicze" [Journal of Law], a journal published by the Cardinal Stefan Wyszyński University. The major translator for this series is Anna Tarwacka, who, apart from the above strictly legal sources, has also translated portions of Noctes Atticae.

Already at first glance, the relatively small number and narrow scope of the presented translations may be surprising. Some of these published translations omit the original source text ${ }^{9}$.

When assessing the editing and translation of legal documents from Roman times, a certain selectivity can be seen. The following trends can be said to exist:

- chronology, in the following order: leges regiae, lex XII tabularum, Institutes of Gaius, Institutes of Justinian, a few passages from the Digest of Justinian, the Book of the Eparch, and the latest publication: Digesta Iustiniani. The Digest of Justinian,

- a gradual change from publishing only Polish translations to bilingual texts, where the original can be directly compared with its translated version,

- the predominance of more compact forms; although these works are important for research and teaching, they are not as monumental as some of the others, for example the Institutes of Gaius or the Institutes of Justinian. However, the publication of the original and the translation of the first eleven books of The Digest of Justinian have been an exception to this,

- as far as the content of published works is concerned, three different subjects are noticeable:

- general law: Ustawa XII tablic. Zbiór prawa Mojżeszowego $i$ rzymskiego [The Lex of XII Tables] by Maria and Jan

No publisher given. National Scheme for Humanities Development.

S. Łoś, Zachowane fragmenty Prawa XII Tablic [Known Fragmens of Lex XII Tables], Warszawa: Pax 1958; Institutes of Justinian, C. Kunderewicz (transl.), Warszawa: Państwowe Wydawnictwo Naukowe 1986. 
Zabłocki, O różnych regułach dawnego prawa [About Various Rules of Early Law] by Tomasz Palmirski, and the Digest of Justinian edited by the same author,

- civil law: two translations of the Institutes of Gaius: Gaius, Instytucje [Gaius, Institutions] by Cezary Kunderewicz and Gai Institutiones by Władysław Rozwadowski,

- public law: Antoni Dębiński, Elżbieta Loska, Anna Tarwacka, Dorota Stolarek from the books of the Digest of Justinian. Text and translation in the "Zeszyty Prawnicze" [Journal of Law] journal, as well as the entire Book I of the Digest translated by Bartosz Szolc-Nartowski, and a translation by Bronisław Sitek - Tabula Herecleensis.

Furthermore, the public law related works can be subdivided according to two more themes: the criminal law and the legal system. The former is represented by Dorota Stolarek and Antoni Dębiński, and the latter by Anna Tarwacka and Bronisław Sitek.

The conclusion is that the current research trends are varied and numerous, with the most prominent being the translations of general and civil law sources. Both of these categories are characterised by cohesive editing. As regards Roman public law, the subjects discussed in academic works are "scattered". Nevertheless, a "new wave" of research interest is emerging, concerned with the Roman legal system. Undoubtedly, these latest published sources, once they have been fully translated, will become a major learning base for further, detailed and innovative academic research.

At the same time, it is important to note the huge recent editing achievement, which is the publication of the first two volumes of the Digest of Justinian (11 books): Digesta Iustiniani, containing the original text (Greek and Latin) accompanied by translations. A work of such significance will be a great help for future research on Roman law in Poland. 
